\title{
Comment
}

\section{Trans Union Reconsidered}

\author{
Jonathan R. Macey $\nmid$ and Geoffrey P. Miller+t
}

"There will never be another Van Gorkom.""

Smith v. Van Gorkom ${ }^{2}$ (the Trans Union case) is now well-established as one of the most important-and mystifying-corporate law cases of the decade. The Delaware Supreme Court stunned and dismayed the corporate bar by holding that a board of directors violated its duty of care to shareholders by failing to exercise sufficient deliberation before approving a cash-out merger at a fifty percent premium over the market price. The case seemed to augur broad new liability for corporate directors. It immediately received widespread attention, both because it carried important implications for corporate counseling and because it suggested that the Delaware courts might be prepared to increase the rights of shareholders as against incumbent boards under the Business Judgment Rule. ${ }^{3}$

Not surprisingly, Trans Union sparked lively debate among commentators. Most have disparaged the decision for undermining the Business

$†$ Professor of Law, Cornell Law School.

H Associate Dean and Professor of Law, University of Chicago Law School. We would like to thank Leon Greenfield for excellent research assistance, and Daniel Fischel, Dale Oesterle and John Siliciano for useful comments.

1. Mr. Justice Moore, at oral argument in Moran v. Household Int'l, Inc., 500 A.2d 1346 (Del. 1985) (May 21, 1985).

2. Smith v. Van Gorkom, 488 A.2d 858 (Del. 1985).

3. The Business Judgment Rule provides generally that courts will not second-guess actions of corporate boards of directors which reflect the exercise of reasonable business judgment, even if those actions turn out to have been mistaken in the light of hindsight. For general background on the Business Judgment Rule, see D. Block, N. Barton \& S. Radin, The Business Judgment Rule: Fiductary Duttes of Corporate Directors and Officers (1987); M. Lane, Representing CORPORATE OFFICERS AND DIRECTORS 43-86 (1987); Arsht, The Business Judgment Rule Revisited, 8 HofsTra L. REV. 93 (1979). 
Judgment Rule. ${ }^{4}$ Others have praised it for the same reason. ${ }^{5}$ Still others see the case as not representing any significant change in prior law. ${ }^{6}$

None of these positions adequately explains the decision. They all share the same defect: they attempt to analyze the case within the standard conceptual framework of the Business Judgment Rule. Within this framework, the case seems anomolous, to say the least, and quite possibly misguided. But Trans Union is not, at bottom, a business judgment case. It is a takeover case. Its function is to regulate a target's response to certain types of takeover bids, namely "rush" offers with short time fuses. Seen in this light, it fits easily with other recent Delaware decisions.

The view of Trans Union as a takeover case has implications for corporate counseling. Although the case does suggest that corporate boards should take additional precautions in the procedures they use in making major decisions, it does not pose a serious threat of liability to officers and directors. The case should not be understood as interfering with the broad discretion given to corporate boards under the Business Judgment Rule outside the takeover context.

Further, it is necessary to understand Trans Union as a takeover case in order to make coherent judgments about whether the case was rightly or wrongly decided. The answer to that question depends on an empirical analysis of whether the costs of the rule, namely increased transaction costs and reduced likelihood that a control transaction will occur, exceed the benefits of stimulating auctions that enhance shareholder welfare and increase economic efficiency. This Comment concludes that the costs of the Trans Union case most likely exceed the benefits. We therefore join the majority of commentators who question the wisdom of the decision, although our reasons for doing so differ markedly from those advanced in prior work.

4. E.g., Fischel, The Business Judgment Rule and the Trans Union Case, 40 Bus. Law. 1437, 1455 (1985) ("surely one of the worst decisions in the history of corporate law"); Herzel \& Katz, Smith v. Van Gorkom: The Business of Judging Business Judgment, 41 Bus. LAw. 1187 (1986) ("misguided"); Manning, Reflections and Practical Tips on Life in the Boardroom After Van Gorkom, 41 Bus. LAw. 1 (1985) (suggesting, however, that Delaware courts will not apply case's language stringently).

5. E.g., Chittur, The Corporate Director's Standard of Care: Past, Present, and Future, 10 DEL. J. CoRp. L. 505, 543 (1985) ("Trans Union is a long-overdue judicial affirmation of the need for better informed directors and, consequently, more responsible corporate behavior.").

6. E.g., Moskin, Trans Union: A Nailed Board, 10 Del. J. CoRP. L. 405, 428 (1985); Prickett, An Explanation of Trans Union to "Henny-Penny" and Her Friends, 10 DeL. J. CoRP. L. 451 (1985) (author was counsel to the plaintiffs in Trans Union); Quillen, Trans Union, Business Judgment, and Neutral Principles, 10 DEL. J. CoRP. L. 465 (1985) (author's firm represented the individual defendants); Radin, The Director's Duty of Care Three Years After Smith v. Van Gorkom, 39 Hastings L.J. 707 (1988); Schwartz \& Wiles, Trans Union: Neither "New" Law nor "Bad" Law, 10 DEL. J. CORP. L. 429 (1985). One commentator has suggested that the opinion was based partly on a perceived breach of the duty of loyalty. Kirk, The Trans Union Case: Is it Business Judgment Rule as Usual?, 24 AM. Bus. L.J. 467 (1986). 


\section{Trans Union as a Business Judgment Case: Difficulties with the Gonventional Analysis}

When viewed in conventional terms, as a business judgment case, Trans Union presents a number of perplexing problems. First, although the court defined the applicable standard of care as gross negligence, it seemed to apply a more stringent standard on the facts of the case. Second, Trans Union appears to depart dramatically from prior law and to upset settled expectations, a suprising result for a court widely known for its predictability. Third, Trans Union apparently displays a mysterious antimanagement bias even though the Delaware courts have a reputation for favoring incumbent managers. Finally, the remedy prescribed by Trans Union appears to be largely cosmetic and even self-defeating, despite the Delaware courts' reputation for comptence in corporate law matters.

\section{A. The Gross Negligence Standard and the Facts}

While the majority opinion claimed to have articulated a "gross negligence" standard as governing the case, ${ }^{7}$ the facts did not support a finding of negligence, much less gross negligence. There was no suggestion that the board of five inside and five outside directors acted out of any improper motive. ${ }^{8}$ Their credentials and business experience were superb. ${ }^{9}$ The merger had been negotiated by Van Gorkom, the Trans Union Chairman, an attorney and certified public accountant who had many years of experience with the corporation and owned a substantial block of stock. ${ }^{10}$

Most important, the economic rationale for the merger was obvious: Trans Union possessed valuable tax credits that it could not use but that could be sold to the bidder through a merger. ${ }^{11}$ The board acted quickly, not because it failed to understand the gravity of its decision, but because the bidder had insisted that it respond to the proposal within three days. ${ }^{12}$ The board had been warned by counsel that failure to approve the merger might result in personal liability. ${ }^{13}$ The purchase price of $\$ 55$ a share, representing a fifty percent premium over market, hardly seemed inadequate, particularly since the firm's shares were publicly traded, and had never traded at a price higher than $\$ 391 / 2{ }^{14}$ After the board originally

7. Trans Union, 488 A.2d at 873 .

8. Id.

9. See id. at 868. At the time of the merger the five inside directors had served on corporate boards of directors for a combined total of 68 years, and the five outside directors had 53 years cumulative service as Trans Union directors. Id. at 894 (McNeilly, J., dissenting).

10. Id. at 865-66; see Ruling in, Jury Still Out on Trans Union, Chicago Tribune, Feb. 8, 1987, $\S 7$, at 3 , col. 2 .

11. Trans Union, 488 A.2d at 864-65.

12. Id. at 867 .

13. Id. at 868 .

14. See id. at 866 n.5. 
approved the merger, it met again to reconsider the matter. ${ }^{15}$ Shareholders overwhelmingly approved the merger. ${ }^{16}$

In short, the facts, the ostensible legal standard, and the holding are contradictory. Commentators have attempted to resolve this puzzle in two ways. Most attempt to conform the law to the facts, by positing that gross negligence was not the actual rule applied by the court. ${ }^{17}$ They argue that although the court maintained the rhetoric of gross negligence, the case signalled a significant tightening of the standard.

This reasoning, however, is not particularly satisfactory. If the court wanted to signal a change in the law, it need not have relied so explicitly on a gross negligence standard, which had been expressly adopted only a year earlier in a quite different context. ${ }^{18}$ Moreover, subsequent Delaware decisions utterly fail to document any change in the applicable standard of care in the wake of Trans Union. ${ }^{19}$

A minority of commentators have attempted to conform the facts to the gross negligence standard articulated by the majority. ${ }^{20}$ They focus on certain facts, highlighted in the majority opinion, that tend to impeach the thoroughness of the board's deliberations. Van Gorkom negotiated the merger without consulting the rest of the board. ${ }^{21}$ The board approved the merger in a two-hour meeting, without examining the underlying merger documents. ${ }^{22}$ No outside expert such as an investment banker was consulted as to the fairness of the purchase price. ${ }^{23}$ The agreement prohibited Trans Union from soliciting competing bids and gave the bidder an option to purchase one million shares at a slight premium over the thenprevailing market price, which it could resell if a higher bidder appeared. ${ }^{24}$ The agreement was signed by Van Gorkom in his study while he was hosting a party for the Chicago Lyric Opera. ${ }^{25}$

These facts do not, in the opinion of most observers, establish anything

15. Id. at $869-70$.

16. Id. at 870 .

17. See Note, Corporations - Directors Who Approve Sale of Corporation Without Sufficient Deliberation Not Entitled to Protection Afforded by Business Judgment Rule - Smith v. Van Gorkom, 488 A.2d 858 (Del. 1985), 16 SETON HALL L. REv. 242, 271-72 (1986) [hereinafter Seton Hall Note] (arguing that court "applied the much stricter standard of simple negligence"); see also Fischel, supra note 4, at 1445 (arguing that gross negligence is not plausible explanation for facts); Quillen, supra note 6 (criticizing case for being incorrectly decided on its facts and insufficiently principled); Comment, Mining the Safe Harbor? The Business Judgment Rule After Trans Union, 10 DEL. J. CoRP. L. 545, 567 (1985) (arguing that court deemed grossly negligent actions that undoubtedly would have been safe before Trans Union).

18. Aronson v. Lewis, 473 A.2d 805, 812 (Del. 1984) (derivative action charging waste of corporate assets).

19. See infra note 68 .

20. E.g., Prickett, supra note 6; Radin, supra note 6, at 754 .

21. Trans Union, 488 A.2d at 866-67.

22. Id. at $868-69$.

23. Id. at 876 .

24. Id. at 868 .

25. Id. at 869 . 
like gross negligence. ${ }^{26}$ Many corporate decisions of equal moment are made with less deliberation. The board had no reason to question the sincerity of the bidder or the fairness of the purchase price. Indeed, given that the deal appeared to be so favorable, the board surely was entitled to some leeway in the formality of the procedures which it used to evaluate the matter.

Moreover, the court seemed determined to make an example of the Trans Union board: it overturned the trial court's fact-finding, ${ }^{27}$ and it rejected the board's defense that any defects had been ratified by shareholder approval, on the somewhat strained ground that the board had failed to make full disclosure in the proxy statement. ${ }^{28}$ In addition, the Delaware courts have rejected a number of challenges to board deliberations that seemed no more careful than the actions deemed inadequate in Trans Union. ${ }^{29}$ Thus, viewing the case as being rightly decided on the basis of a gross negligence standard is not a particularly satisfying way of reconciling the apparent inconsistency between the facts and the law.

\section{B. The Surprising Departure from Settled Business Judgment Law}

The outcome of the case was exactly opposite to what virtually every observer of Delaware law would have predicted. ${ }^{30}$ Prior case law had suggested that when a corporate decision was challenged, the Business Judgment Rule provided a safe harbor to board members so long as (1) there was no self-dealing or conflict of interest; (2) the board actually addressed and decided the issue, rather than neglecting it; (3) the board members properly informed themselves prior to reaching a decision; and (4) the board's actions were not completely unjustifiable or irrational. ${ }^{31}$ The actions criticized by the court in Trans Union surely would have been protected under this safe harbor approach.

It is widely understood that both the Delaware courts and the members of the bar specializing in Delaware corporate law place an extremely high

\footnotetext{
26. See infra note 30 .

27. E.g., Trans Union, 488 A.2d at 871,880 .

28. Id. at $890-93$.

29. See, e.g., Moran v. Household Int'l, Inc., 493 A.2d 946 (Del. 1985) (upholding board's decision, reached after cursory debate, to approve novel "poison pill" plan which fundamentally altered rights of shareholders and management); see also cases cited infra note 68.

30. See Spiegel, The Liability of Corporate Officers, A.B.A. J., Nov. 1985, at 48, 51 (discussing liability exposure of corporate directors in wake of Trans Union); Leisner, Boardroom Jitters: $A$ Landmark Court Decision Upsets Corporate Directors, Barron's, Apr. 22, 1985, at 34 (same); A Landmark Ruling that Puts Board Members in Peril, Business Week, Mar. 18, 1985, at 56 (same); No More Easy Street for Company Directors, U.S. News \& World Report, Mar. 4, 1985, at 95 (same); Borden, First Thoughts an the Decision in Delaware on Trans Union, N.Y.L.J., Feb. 25, 1985, at 1, col. 3 (same).

31. E.g., Aronson v. Lewis, 473 A.2d 805, 812 (Del. 1984) (directors must be disinterested and informed); Sinclair Oil Co. v. Levien, 280 A.2d 717, 720 (Del. 1971) (board's decisions will not be disturbed "if they can be attributed to any rational business purpose"); Gimbel v. Signal Cos., 316 A.2d 599, 609 (Del. Ch.) (application of rule depends on showing that informed directors did, in fact, make business judgment), affd, 316 A.2d 619 (Del. 1974).
} 
value on consistency and predictability ${ }^{32}$ These features are highly valued because they facilitate planning and reduce the risks of corporate action. Indeed, one of the key ingredients of Delaware's recipe for success in the competitive market for corporate charters is the degree to which Delaware law provides reasonably certain and reliable rules to govern behavior. The Trans Union case appears especially problematic in light of Delaware's justified reputation for consistency, since under at least one interpretation it worked a dramatic and unanticipated change, muddied a previously well-understood area of law, and imposed unforeseeable and devastating economic penalties on a corporate board..$^{33}$

The existing literature again resolves this problem in two ways. Most commentators view Trans Union as an exception to the general pattern in Delaware, a rare case that changes the law without prior warning and leaves it in a confused and unsatisfactory condition. ${ }^{34}$ This view is not particularly satisfying, however, since it posits that the Delaware Supreme Court inexplicably deviated from a course it had consistently, and, for Delaware, profitably followed theretofore. Other writers suggest that Trans Union was consistent with prior cases and not unanticipated after all. ${ }^{35}$ But the evidence is overwhelming that the decision shocked and amazed a large segment of the corporate bar. ${ }^{36}$ The existing analyses of Trans Union do not adequately explain why the court suddenly altered the ground rules.

\section{The Apparent Anti-Management Bias}

Trans Union is also problematic because it appears to be anti-management. The case severely penalized members of a corporate board by saddling them with potentially devastating personal liability. ${ }^{37}$ The tone of

32. See Macey \& Miller, Toward an Interest-Group Theory of Delaware Corporate Law, 65 Tex. L. Rev. 469, 484 (1987); Romano, Law as a Product: Some Pieces of the Incorporation Puzzle, 1 J.L. ECON. \& ORG. 225, 277 (1985).

33. Delaware corporate law has been developing in the way Bayless Manning claims common law often develops - "in a manner reminiscent of a shipboard passenger making his way from the bar to his stateroom, careening first against one bulkhead and then thrown against the other." Manning, supra note 4 , at 2 .

34. See Seton Hall Note, supra note 17, at 269; Herzel \& Katz, supra note 4, at 1190-91.

35. E.g., Burgman \& Cox, Corporate Directors, Corporate Realities and Deliberative Process: An Analysis of the Trans Union Case, 11 J. Corp. L. 311, 320 (1986); Prickett, supra note 6; Schwartz \& Wiles, supra note 6. Some, such as Manning, supra note 4, at 4, suggest that even if out of line with other Delaware cases, Trans Union will eventually be "fitted . . . into the mainstream of business judgment rule jurisprudence."

36. See, e.g., Herzel \& Katz, supra note 4, at 1188; Manning, supra note 4, at 1; sources cited supra note 30 .

37. The case was eventually settled for $\$ 23.5$ million, an amount far in excess of the $\$ 10$ million limit on the company's directors' liability policy. See Smith v. Van Gorkom, No. 6342 (Del. Ch. Oct. 11, 1985); Seton Hall Note, supra note 17, at 273. Most of the board's damages were eventually paid by the acquiror. Pritzkers Foot Director's Bill for Trans Union Settlement, Crain's Chicago Business, Aug. 12, 1985, at 19 . However, the directors did have to pay roughly $\$ 2.5$ million out of their own pockets. Van Gorkom himself picked up the tab for the company's five outside directors. Ruling In, Jury Still Out on Trans Union, Chicago Tribune, Feb. 8, 1987, § 7, at 9, col. 4. 
the opinion was harsh and uncharitable towards the defendants, sounding at times, as Justice McNeilly observed in dissent, more like "an advocate's closing address to a hostile jury"38 than an impartial judicial opinion. This aspect of the case appears anomolous in light of Delaware's longstanding reputation as a jurisdiction that protects the interests of management. In the words of Professor William Gary, the most prominent exponent of this theory, Delaware has promoted a "race for the bottom" in corporate regulation by failing to protect shareholders against actions by the incumbent management of Delaware corporations. ${ }^{39}$ Although some have rejected Cary's harsh criticism of Delaware, ${ }^{40}$ his assessment of Delaware law as generally giving great discretion to corporate managers is still universally accepted. ${ }^{41}$ Why should the Delaware Supreme Court suddenly deviate from this pattern and impose new restrictions on management discretion, backed by the in terrorem threat of massive personal liability?

The existing literature has several explanations for this puzzle. Some scholars take the position that Trans Union signals a shift in Delaware case law towards more stringent regulation of management behavior. ${ }^{42}$ According to Professor Fischel, the court appears finally to have come under the spell of Professor Cary, a development that he views as unfortunate. ${ }^{43}$ Other scholars who endorse the Gary approach agree that Trans Union presages increased regulation of managers, but view this as a desirable development." The thesis that the Delaware court has converted to Caryism is, however, exceedingly difficult to credit. There is no reason why the Delaware courts should suddenly depart from a strategy that has proved so remarkably successful over many years. Furthermore, a strong anti-management bias simply cannot be discerned either in opinions is-

38. Trans Union, 488 A.2d at 893 (McNeilly, J., dissenting).

39. Cary, Federalism and Corporate Law: Reflections Upon Delaware, 83 YALE L.J. 663, 705 (1974).

40. In recent years, scholars associated with the law and economics movement have argued that rules apparently favoring management may also be in the best interest of shareholders. See, e.g., $\mathbf{R}$. POSNER, ECONOMIC ANAlYsis OF LAW 389-92 (3d ed. 1986); R. Winter, Government aND THE CORPORATION 28-42 (1978); Baysinger \& Butler, The Role of Corporate Law in the Theory of the Firm, 28 J.L. \& EcoN. 179 (1985); Fischel, The "Race to the Bottom" Revisited: Reflections on Recent Developments in Delaware's Corporation Law, 76 Nw. U.L. REv. 913 (1982). For a suggestion that both approaches are partly true, see Macey \& Miller, supra note 32.

41. Even law and economics theorists who reject the Cary thesis of a "race for the bottom" acknowledge that managers generally enjoy broad discretion under Delaware law. See, e.g., Fischel, supra note 40; Winter, State Law, Shareholder Protection, and the Theory of the Corporation, $6 \mathrm{~J}$. LEGAl. STUd. 251 (1977).

42. See Herzel \& Katz, supra note 4, at 1188; Chittur, supra note 5, at 527; Seton Hall Note, supra note 17, at 269; Comment, supra note 17 , at 566 .

43. Professor Fischel suggests that, although Cary's position is now "discredited" in scholarly circles, "[ $t$ ) he one entity that appears to have been most influenced by Cary is the Delaware Supreme Court." Fischel, supra note 4, at 1454.

44. E.g., Chittur, supra note 5, at 527 ("With the Trans Union decision, Delaware has confounded its critics by signaling that the 'race to the bottom' is over. At the least, Delaware is no longer the winner."). 
sued around the time of Trans Union ${ }^{45}$ or in those that have appeared since. $^{46}$

Other scholars suggest that Trans Union does not represent an antimanagement decision. ${ }^{47}$ They note that the case contains rhetoric helpful to management in future cases, that it penalized only egregious behavior, and that Delaware has always protected shareholders against management malfeasance. Yet no one would seriously argue that Delaware has been a leader among chartering states in restricting management discretion. Delaware has always afforded shareholders protection against serious management abuse. But the facts of Trans Union did not establish any serious abuse. Accordingly, Trans Union cannot be satisfactorily explained either as part of an anti-management trend in Delaware law or as a continuation of existing limitations on management discretion.

\section{The Ineffectiveness of the Remedy}

Finally, Trans Union is perplexing because the remedy prescribed by the court appeared to be purely a nostrum. The opinion strongly suggests, and many commentators have noted, that corporate managers faced with a situation like that confronting the Trans Union board can insure against liability by creating a paper record demonstrating that the board has engaged in due deliberations. ${ }^{48}$ Most importantly, a board can substantially insulate itself by obtaining an opinion of an investment banker as to the fairness of the transaction. ${ }^{49}$ A corporation's lawyers can also insulate the board by making sure that the members are provided advance copies of all documents reflecting a proposed transaction, and that the minutes reflect a full and extended discussion of the pros and cons. ${ }^{50}$ Such procedures, however, do not provide any reliable guarantee that the transaction will benefit shareholders. Fairness opinions of investment bankers are notorious for the degree to which they can be induced to reflect the wishes of the in-

45. See, e.g., Pogostin v. Rice, 480 A.2d 619 (Del. 1984); Weinberger v. UOP, Inc., 457 A.2d 701 (Del. 1983). Weinberger substantially reversed the two cases cited by Professor Fischel as evidencing an anti-management strain in Delaware decisions: Singer v. Magnavox Co., 380 A.2d 969 (Del. 1977), and Lynch v. Vickers Energy Corp., 429 A.2d 497 (Del. 1981).

46. E.g., Ivanhoe Partners v. Newmont Mining Corp., 535 A.2d 1334 (Del. 1987) (allowing takeover defense measures on finding that they were taken in good faith after reasonable investigation); Unocal Corp. v. Mesa Petroleum Co., 493 A.2d 946 (Del. 1985) (allowing corporate self-tender that excluded hostile bidder from participation); Moran v. Household Int'l, Inc., 500 A.2d 1346 (Del. 1985) (allowing corporation to create poison pill even when no specific hostile offer threatened).

47. E.g., Burgman \& Cox, supra note 35, at 320-26; Schwartz \& Wiles, supra note 6, at 447-49.

48. See Moskin, supra note 6, at 427-28; Schwartz \& Wiles, supra note 6, at 445-46. For an insightful list of corporate planning strategies in the wake of Trans Union, see Manning, supra note 4 , at $8-14$.

49. The court declined to require an outside valuation, but suggested that the existence of such an opinion would be given considerable weight in any duty of care suit. Trans Union, 488 A.2d at 875-78.

50. It probably would be wise to consult on any controversial matter with counsel from the state of Delaware. See, e.g., Prickett, supra note 6, at 458 n.28. 
cumbent board. ${ }^{\mathbf{}}$ Even if board members are provided with advance copies of merger documents, there is no guarantee they will read them carefully, and even if they do, the degree to which anyone but a lawyer can comprehend the fine print is suspect.

Some commentators, recognizing the problem, throw up their hands and conclude that the court has mandated procedures which are useless, or which indeed are worse than useless because they amount to a "tax" on corporate control transactions, the costs of which fall on Delaware corporations and their shareholders and the benefits of which accrue to investment bankers and lawyers in other states. ${ }^{52}$ But it is highly unlikely that the Delaware Supreme Court, widely recognized as one of the nation's ablest and most experienced in matters of corporate law, ${ }^{\mathbf{6 3}}$ would adopt a rule with such self-defeating consequences. Other commentators have applauded the increased formality of board deliberations that the opinion is likely to induce, on the ground that the consequence will be more informed decisionmaking. ${ }^{\text {. }}$ However, when the putative benefits of increased formality are weighed against the costs, especially the multimillion dollar fees charged by investment banks, the argument that the enhanced procedures are beneficial is not particularly convincing.

\section{Trans Union as a Takeover Gase}

As the preceeding discussion demonstrates, the received understanding of Trans Union fails to explain a number of perplexing aspects of the case. In our view, the defects in the conventional analysis arise from the fact that the case has been uniformly perceived as a business judgment case. Many of the difficulties can be overcome if it is conceptualized, not as a business judgment case, but as a takeover case. ${ }^{\mathrm{s5}}$

The key to understanding the case is that the bidder, Marmom Group, placed a stringent time deadline on the board's response to the bid. If the board did not accept the bid within three days, Marmom threatened to withdraw the offer. From the standpoint of the acquiror, this kind of bid is one method of ensuring that the acquiror does not expend its resources

51. Readers can draw their own conclusions from the behavior of the investment bank in Solash v. Telex Corp., Fed. Sec. L. Rep. (CCH) If 93,608 (Del. Ch. Jan. 19, 1988). Even the Delaware Supreme Court is suspicious of the reliability of fairness opinions, at least when they serve the interests of acquirors. See Weinberger v. UOP, Inc., 457 A.2d 701, 712 (Del. 1983) (investment bank brought fairness opinion to directors' meeting with price left blank).

52. E.g., Fischel, supra note 4, at 1453-54; Herzel \& Katz, supra note 4, at 1191-92.

53. See, e.g., Macey \& Miller, supra note 32, at 484-87, Romano, supra note 32, at 280.

54. E.g., Burgman \& Cox, supra note 35; Comment, Limiting Corporate Directors' Liability: Delaware's Section 102(b)(7) and the Erosion of the Directors' Duty of Care, 136 U. PA. L. REV. 239, 250 (1987); Prickett, supra note 6, at 462 ("directors will be more fully informed and better able to evaluate management's recommendations, rather than just rubber-stamping them.").

55. The view of Trans Union advanced here has not, to our knowledge, previously been proposed in the literature, other than in a passing comment in an earlier article by the present authors. See Macey \& Miller, supra note 32 , at 517-19. 
to put a target "in play" - by researching the target's value, obtaining financing commitments, drawing up merger documents and the like only to have the prize snatched away by a later, higher bidder. ${ }^{88}$

From the standpoint of the target's board, however, a rush bid can create an exceptionally difficult problem, especially if, as in Trans Union, the initial bid represents a big premium over market. If the board rejects the bid, or fails to act within the deadline, the acquiror may drop the bid. Because the deadline for decision is so short, the board must make its decision without any assurance that if the bidder drops out, another, higher bidder will appear. Thus, in rejecting a bid or failing to act in a timely fashion, the board may harm shareholders and, at worst, may become subject to possible liability for failing to sell the company at a favorable price. ${ }^{\text {sz }}$ If, on the other hand, the board accepts the rush bid, it thereby substantially reduces the possibility that an auction will develop for the company in which the price paid to shareholders is driven well above the initial bid. This too can lead to board liability. ${ }^{58}$

The damages remedy imposed by Trans Union provides a solution to the board's dilemma. After Trans Union, a board faced with a rush bid need only say: "we can't possibly accept your bid by the deadline because we need time to obtain the opinion of an outside investment banker as to its fairness." Trans Union eliminates the possibility that the board of a Delaware corporation will be held liable to shareholders if it delays making a decision and the bidder thereupon drops its offer. By eliminating this possibility, the Delaware Supreme Court has removed one horn of the dilemma. This is the crucial mechanism by which the Gourt has ensured that future boards will not face the quandary of the Trans Union directors, who feared liability for not accepting the bid.

The breathing space offered by Trans Union gives the board the one resource that is most crucial in a takeover contest: time. During the period in which the investment bank is preparing a fairness opinion (and an investment bank sensitive to its customer's needs might conclude that a thorough opinion takes a good while to prepare) the incumbent board, if it wants to remain independent, can marshal its takeover defenses. It can

56. See generally Bebchuk, The Case for Facilitating Competing Tender Offers, 95 HARv. L. REv. 1028 (1982).

57. The court in Trans Union specifically held that despite the time constraints imposed by the acquiror, there was no "exigency of a crisis or emergency" present justifying any reduction in the quality of board deliberation. Trans Union, 488 A.2d at 874.

58. The rush bidder will always, as in Trans Union, insist that the board provide assurances that other bidders will not be encouraged to use the first bid to begin a bidding war. In Trans Union those assurances were provided by the board's commitment not to solicit other bids, and by the acquiror's option to purchase a large amount of the target's stock at close to the pre-existing market price for resale at a profit if a third party succeeded with a higher bid. Id. at 868 . The majority opinion found unpersuasive the defendant's claim that they had negotiated a bona fide "market test" period during which the fairness of the offer price could be tested through the development of an auction. Id. at 878-80.

59. This consequence of the case is noted in passing in Schwartz \& Wiles, supra note 6, at 448. 
seek out a white knight, adopt a poison pill, buy or sell off assets, leverage up its capital structure, or adopt whatever other defensive measure may be effective under the circumstances. Then, when the investment bank returns with the expected opinion that the offer is "grossly inadequate", the target will be well-prepared to reject the offer and fend off the expected assault.

If, on the other hand, the board wishes to accept the offer, it can arrange for a speedy opinion by the investment bank stating that the offer price is fair to shareholders and that immediate acceptance of the offer is imperative. The board can then meet and, after carefully documented discussion about the pros and cons of the offer, can approve the proposal with virtually iron-clad assurance that they will face no personal liability for their actions. In short, Trans Union greatly enhances the flexibility of an incumbent board in dealing with the difficulties inherent in takeover bids.

Thus, under our reading of Trans Union, statutes permitting corporations to absolve directors from personal liability for breaches of their fiduciary duty of care ${ }^{60}$ do not "overrule Trans Union" as is sometimes supposed. ${ }^{61}$ Rather, such statutes achieve a purpose that is virtually identical to the result reached in Trans Union by providing a mechanism by which the boards of directors of covered corporations can relieve themselves of personal liability for certain corporate decisions. ${ }^{62}$

The Trans Union decision benefits incumbent boards in one other respect. At the heart of the decision is the court's judgment that the board had acted without sufficient information on which to base a determination of the intrinsic value of Trans Union as a going concern. ${ }^{63}$ The court rejected the argument that the merger price of $\$ 55$ per share was adequate because it represented a substantial premium over market price, opining instead that "the market had consistently undervalued the worth of Trans Union's stock." "64

The court's rejection of the efficient capital markets hypothesis ${ }^{65}$ pro-

60. E.g., Del. Code ANN. tit. 8, § 102(b)(7) (Supp. 1986). Twenty-five states have adopted statutes that authorize the adoption of charter amendments that reduce or eliminate a director's liability for violations of the fiduciary duty of care. See 2 MODEL Business CoRP. ACT ANN. 1094 (3rd ed. Supp. 1988).

61. See, e.g., Note, Delaware's Limit on Director Liability: How the Market for Incorporation Shapes Corporate Law, 10 Harv. J.L. \& Pub. Pol'y 665 (1987).

62. These statutes do alter the result reached in Trans Union in one significant respect. Directors who are absolved by statute from personal liability for breaches of their fiduciary duty of care no longer will have an incentive to advise the creation of a heavy "papering" of corporate decisionmaking as a means of avoiding such liability. But a paper record will still be desirable as a means of insulating the directors and the corporation from suits for injunctive relief. Corporate attorneys will also press for heavy "papering" of transactions in order to insulate themselves from potential legal malpractice claims. And, of course, the directors of those corporations that have not chosen to absolve their directors of liability will still have an incentive to develop such a paper record.

63. Trans Union, 488 A.2d at 876 .

64. Id.

65. See id. at 876. The efficient markets hypothesis posits that the market price of a widely traded 
vides an additional protection for incumbent boards fighting hostile offers. Because such offers are always made at a large premium over the preexisting market price, it is difficult to justify defensive maneuvers if the efficient capital markets hypothesis is accepted. ${ }^{68}$ In rejecting the hypothesis and holding that a company can have an "intrinsic" value different from its present marketplace value, the Trans Union court provided doctrinal support for all sorts of potential defensive maneuvers by target boards. $^{67}$

When understood as a takeover case, the perplexing features of Trans Union noted in Part I become quite unproblematic. The apparent discrepancy between the articulated legal standard of gross negligence and the facts can readily be explained as reflecting the Delaware Supreme Court's wish to fashion a speedy remedy to the perceived problem of "coercive" rush offers. The court in effect made an example of the Trans Union board in order to protect incumbent boards in the future. Holding the board members liable was sure to send the strongest possible message to the corporate bar that rush offers need not be entertained. Yet future boards of directors should not fear liability. The gross negligence standard is rhetorically high enough to insulate the actions of virtually any board so long as extreme dereliction of duty is not shown. ${ }^{88}$ Further, as noted earlier, future boards can easily protect themselves from liability by making a show of due deliberation and by obtaining a suitable fairness opinion from an investment banking firm. Similarly, and perhaps more importantly, the opinion in Trans Union will make it easier for boards to prevent hostile bidders from obtaining injunctive relief against target boards who engage in defensive tactics that forestall auctions for firms already "in play," because target management can invoke Trans Union to argue that such de-

security will reflect all public information about the value of the stock. See generally Gilson \& Kraakman, The Mechanisms of Market Efficiency, 70 VA. L. REv. 549 (1984).

66. But not impossible. See Bebchuk, supra note 56 (endorsing solicitation of competing bids).

67. We are grateful to Professor Ron Gilson for this observation. Of course, Trans Union is not unique in its rejection of the efficient capital markets hypothesis. Other Delaware opinions, particularly Weinberger v. UOP, Inc., 457 A.2d 701, 712-13 (Del. 1983) also have rejected the hypothesis. However, the reaffirmation of the rejection of the efficient capital markets hypothesis in Trans Union is noteworthy because other courts with influence and expertise in corporate law matters have firmly embraced the hypothesis. See Basic, Inc. v. Levinson, 108 S. Ct. 978, 990-92 (1988) ("Recent empirical studies have tended to confirm Congress' premise that the market price of shares traded on welldeveloped markets reflects all publicly available information ....."); Dynamics Co. v. CTS Co., 794 F.2d 250, 253 (7th Cir. 1986) ("the market price of publicly traded stock impounds all available information about the value of the stock"), rev'd on other grounds, $107 \mathrm{~S}$. Ct. 1637 (1987).

68. An examination of subsequent Delaware cases reveals that there has been no pattern of increased director liability in the wake of Trans Union. See Unocal Corp. v. Mesa Petroleum Co., 493 A.2d 946 (Del. 1985); Moran v. Household Int'l Inc., 500 A.2d 1346 (Del. 1985); Rosenblatt v. Getty Oil Co., 493 A.2d 929 (Del. 1985); Prime Cornputer, Inc. v. Allen, 1988 Del. Ch. LEXIS 10 (Jan. 25, 1988); Solash v. Telex Corp., Fed. Sec. L. Rep. (CCH) I 93,608 (Del. Ch. Jan. 19, 1988); Grobow v. Perot, 526 A.2d 914 (Del. Ch. 1987). For an analysis of post-Trans Union cases, see Radin, supra note 6, at 709 ("reports of the business judgment rule's demise were, like those of Mark Twain's death, exaggerated."). 
fensive measures are necessary to allow managers sufficient time to consider fully the merits of the competing offers.

While imposing personal liability on a corporate board is difficult to square with traditional Business Judgment jurisprudence in Delaware, providing incumbent board members with means to fend off potentially coercive takeover bids is entirely within the mainstream of recent decisions, and imposing personal liability on the Trans Union board did this most effectively. ${ }^{69}$ Within the past few years the Delaware Supreme Court has issued a number of important opinions in takeover cases favoring enhanced powers for incumbent board members to fend off unwanted takeover bids. ${ }^{70}$ As $\mathrm{Mr}$. Justice Moore once said, "there will never be another Van Gorkom."'71

The mysterious anti-management bias of the Trans Union case also disappears when the decision is viewed in the takeover context. A decision that enhances the level of business judgment scrutiny generally can easily be seen as anti-management. But under our analysis, Trans Union is a pro-management decision. It increases the power of incumbent managers to safeguard their positions and to remain in control of their corporations, at virtually no cost to any board members other than those few who were caught up in the unfortunate web of the Trans Union case itself. The tone of the opinion can also be understood in light of our theory. If the court wanted to send a message to the corporate bar, the uncharacteristically hostile and anti-management tone of the opinion was well-calculated to convey the message as forcefully as possible.

Finally, when viewed as a takeover case, the remedy prescribed by Trans Union is far more than a nostrum. To be sure, the case will increase the use of investment bankers and lawyers in corporate decisionmaking. We agree with the proposition that in general the increased "papering" of board decisions will not substantially raise the level of deliberations. In this respect, the case appears as a boon to investment bankers and lawyers, but as a net cost for shareholders of Delaware corporations and for the nation's economy generally. Yet this perspective is incomplete, for it overlooks the most important feature. In the takeover

69. Chittur, supra note 5 , at 542, suggests that Trans Union imposes stringent limits on an incumbent board's ability to fend off hostile bids, a dubious view in light of the evidence that the case will strengthen the board's power to resist takeovers.

70. See, e.g., Ivanhoe Partners v. Newmont Mining Corp., 535 A.2d 1334 (Del. 1987); Unocal Corp. v. Mesa Petroleum Co., 493 A.2d 946 (Del. 1985); Moran v. Household Int'l, Inc., 500 A.2d 1346 (Del. 1985); Weinberger v. UOP, Inc., 457 A.2d 701 (Del. 1983). The most prominent ostensible exception, Revlon, Inc. v. MacAndrews \& Forbes Holdings, Inc., 506 A.2d 173 (Del. 1986), should be understood as applying only when the sale of a company is inevitable.

Our interpretation of Trans Union is also consistent with recent actions by the Delaware legislature. Section 102(b)(7) of the Corporation Code, enacted in 1986, allows Delaware corporations to limit or eliminate directors' exposure to money damages for duty of care violations. DEL. CoDE ANN. tit. 8, § 102(b)(7) (Supp. 1987). More recently, the legislature adopted powerful new anti-takeover protections for incumbent managers. DeL. CODE ANN. tit. 8, § 203 (1988).

71. See supra note 1 . 
context to which it applies, Trans Union prescribes a potent antidote to rush takeover offers. It is anything but a purely procedural decision when understood in this context.

\section{Policy Implications of the ANalysis}

If our analysis of Trans Union is correct, we must inquire whether the case so interpreted is sound as a matter of social policy. In our view, the answer to that question depends on empirical variables, presently unknown, relating to the costs and benefits of the decision. It is thus impossible to assess the opinion in the abstract. It is possible, however, to identify the relevant variables and to describe their likely magnitude.

The costs of the case are significant. First, the introduction of attorneys' and investment bankers' workproduct as a routine element of many corporate decisions will add substantially to the costs of major transactions involving Delaware firms. These costs, however, may have been overstated in the first flush of dismay following the issuance of the opinion. ${ }^{72}$ If, as we suggest, Trans Union is best understood as a takeover case, the need for "papering" transactions outside the takeover context will be minimal. It is extremely unlikely that Trans Union will ever be applied outside the takeover context, because doing so would not serve its purposes, which are unique to that context. ${ }^{73}$ And even in takeover cases, it is very unlikely, for reasons already stated, that future boards will be held liable for rejecting takeover bids even if the level of deliberation might be questioned under a literal reading of Trans Union. As the bar and corporate boards begin to understand these facts, the amounts spent on protective legal and investment banker opinions may become more manageable.

Second, Trans Union imposes a more subtle, but ultimately more problematic, cost on shareholders of Delaware-chartered firms. The protection against unwanted takeover bids that the case affords is likely in some cases to deter or defeat desirable bids. ${ }^{74}$ As the Delaware Supreme Court has

72. See, e.g., Fishel, supra note 4, at 1454-55.

73. Our analysis thus allays the fears of those, such as Professor Fischel, who believe that Trans Union will lead to more timid behavior by corporate managers in general. See Fischel, supra note 4, at $1453-54$.

74. The empirical evidence is overwhelming that hostile takeovers benefit shareholders of target firms by giving them a substantial premium over the pre-existing market price. See, e.g., Bradley, Interfirm Tender Offers and the Market for Corporate Control, 53 J. Bus. 345, 345-46, 375 (1980) (demonstrating that shareholders of target company gain from takeovers whether or not they tender their shares); Bradley, Desai \& Kim, Synergistic Gains from Corporate Acquisitions and Their Division Between the Stockholders of Target and Acquiring Firms, 31 J. Fin. EcoN. - (1988) (forthcoming) (finding premiums of about $29 \%$ in single bidder offers and $42 \%$ in multiple bidder offers); Dodd \& Ruback, Tender Offers and Stockholder Returns: An Empirical Analysis, 5 J. Fin. EcoN. 351,372 (1977) (concluding that shareholders of target corporations earn "large and significant abnormal returns" in month following announcement of tender offer); Jarrell \& Bradley, The Economic Effects of Federal and State Regulations of Cash Tender Offers, 23 J.L. \& EcoN. 371, 381-82 (1980) (refuting "corporate piracy" theory of takeover effects); Jensen \& Ruback, The Market for Corporate Control: The Scientific Evidence, 11 J. FIN. EcoN. 5 (1983) (summarizing results of thirteen prior studies); Kummer \& Hoffmeister, Valuation Consequences of Cash Tender Offers, $33 \mathrm{~J}$. 
itself noted, a "specter that a board may be acting primarily in its own interests"75 pervades actions taken by incumbent boards to fend off unwanted bidders. Boards may want to fend off offers that actually would be in the shareholders' best interests in order to protect the powers and perquisites of office. ${ }^{76}$

On the other hand, the Trans Union case might be expected to afford some benefits to Delaware firms. First, the case may enhance the quality of the deliberative process within the corporate boardroom, thereby bringing benefits to corporate shareholders in the form of sounder decisionmaking. However, we believe, along with the majority of commentators, that the benefits of such increased deliberation are likely to be small, because of the ease with which corporate boards, aided by a phalanx of sophisticated lawyers and investment bankers, can cloak result-oriented decisionmaking in the guise of careful deliberation.

More importantly, Trans Union will tend to stimulate competitive auctions for target firms. ${ }^{77} \mathrm{~A}$ rush offer by definition is designed to deter an auction by forcing the board to commit early to favoring one bidder. Trans Union, by deterring rush offers, may tend to force certain takeover contests into an auction format in which two or more bidders will compete for the firm. ${ }^{78}$ The result will be to benefit shareholders in many cases by increasing the amounts they are paid for their stock. ${ }^{79}$ Auctions may also have the socially beneficial consequence of directing a firm's assets to the bidder that shows, by its willingness to outbid rivals, that it believes itself to be best able to make productive use of those assets. ${ }^{80}$

But an unrestricted and uncontrolled auction, which, in the market for corporate control, often manifests itself in the form of a protracted bidding

FIN. 505, 516 (1978) (finding that takeovers maximize use of corporate resources and return to shareholders); Office of Chief Economist, Securities and Exchange Commission, The Economics of ANY-OR-All, Partial, ANd Two-Tier Tender Offers (1985) (surveying literature and concluding that takeovers offer substantial economic benefits to shareholders of target firms).

75. Unocal Corp. v. Mesa Petroleum Co., 493 A.2d 946, 954 (Del. 1985).

76. See Easterbrook \& Fischel, The Proper Role of a Target's Management in Responding to a Tender Offer, 94 HARv. L. REv. 1161 (1981); Easterbrook \& Jarrell, Do Targets Gain from Defeating Tender Offers?, 59 N.Y.U. L. REv. 277 (1984); Gilson, A Structural Approach to Corporations: The Case Against Defensive Tactics in Tender Offers, 33 STAN. L. Rev. 819 (1981).

77. See the insightful discussion of the benefits of tender offers in Bebchuk, supra note 56.

78. To the extent that Trans Union is interpreted as requiring an auction for a firm even where the company is not already "in play," it must be regarded as even more intrusive on managerial autonomy than Revlon, Inc. v. MacAndrews \& Forbes Holdings, Inc., 506 A.2d 173 (Del. 1986) (holding that asset lock-up that terminated pre-existing auction for target firm's shares was not in shareholders' interests and should be enjoined). Trans Union, however, should not be interpreted as reaching this result. See supra note 1 and text accompanying notes 59-60 (arguing that Trans Union gives managers time to encourage auction if they think it best, but does not curb managerial decisions to resist hostile takeovers altogether so long as such decisions are fully documented).

79. A recent important study by Bradley, Desai \& Kim, supra note 74, documents the striking increases in target firm shareholder welfare that result from multi-party auctions as compared with single-bid offers.

80. See generally Englebrecht-Wiggans, Auctions and Bidding Model: A Survey, 26 MGMr. Scr. 119 (1980); Banzel, Measurement Cost in the Oranization of Markets, 2 J.L. \& EcoN. 27 (1982); Milgram \& Weber, A Theory of Auctions and Competitive Bidding, 50 Econometrics 1089 (1982). 
war among rival suitors, is not unambiguously good for shareholders. In any auction where bidders must invest resources to determine the appropriate bid price for assets to be sold, each bidder's expected profit falls as the number of bidders increases. ${ }^{81}$ This phenomenon is due to the diminution in probability that any particular bidder will win the auction as well as to the decline in the likely payoff to the winning bidder that occurs when more bidders enter the contest. As a consequence, where an initial bidder knows that an auction may develop for a firm it is attempting to acquire, that bidder will be less likely to bid, since its expected return declines. Thus, to the extent that Trans Union facilitates the creation of an auction market, it may harm shareholders by reducing the probability that they ever will experience a tender offer bid for their shares. ${ }^{82}$

Similarly, economic theory makes it clear that, while asset owners (i.e., target shareholders) who wish to sell their assets can select among a variety of sales techniques, including several different types of auctions, it is they who inevitably bear the pre-bid costs of potential buyers. ${ }^{83}$ In order to minimize the cost of selling their assets, asset owners will employ different sales techniques in different circumstances. ${ }^{84}$

Foremost among the concerns of asset owners who wish to dispose of an asset at the lowest possible cost is the desire to reduce the investment of potential purchasers in acquiring information already in the asset owners' possession. Bidders who are forced to invest resources to acquire such information will reduce the amount they are willing to pay for the asset by the amount spent to acquire it, and asset owners easily can eliminate this cost by providing the information themselves, unless the credibility of the asset owner is at issue. In addition, this information is completely nonproductive; it does not in any way affect the underlying value of the asset. For these reasons, if the value of an asset is likely to be the same to any purchaser (i.e., if the asset is traded on a "thick market") it makes little

81. See French \& McCormick, Sealed Bids, Sunk Costs, and the Process of Competition, $57 \mathrm{~J}$. Bus. 417, 423 (1984).

82. Some commentators, most notably Ronald Gilson, contend that the level of monitoring actually increases where firms conduct an auction since bidders can recoup an informational investment by buying the stock of a target firm and selling to a higher bidder during an auction. In such cases, an auction permits specialization among information gatherers who make initial bids, and managerial teams, who are the ultimate purchasers of the firm at the auction. See Gilson, Seeking Competitive Bids Versus Pure Passivity in Tender Offer Defense, 35 Stan. L. Rev. 51 (1982).

This argument has a surface plausibility, but if Gilson is correct, it is the initial bidder rather than the target firm's management that should make the decision about whether the target firm should be sold at auction. This is because the first bidder has made the initial investment in information about the target, and does not face the same conflict of interest as incumbent management when it makes the decision about whether to promote an auction for the target firm. C.f. Easterbrook \& Fischel, Auctions and Sunk Costs in Tender Offers, 35 STAN. L. REv. 1 (1982) (arguing that even if first bidders could recover their sunk costs in information and earn return on their investment in acquisition of such information, auction would reduce the return on their investment below what they would receive in absence of auction).

83. French \& McCormick, supra note 81, at 425.

84. See Haddock, Macey \& McChesney, Property Rights in Assets and Resistance to Tender Offers, 73 VA. L. Rev. 701 (1987). 
sense to have bidders invest resources in discovering new information about the target.

One way to handle the situation of multiple bidders engaging in a costly search for the value of an asset is to limit the number of firms allowed to bid. ${ }^{85}$ On the other hand, if a particular asset will have a different value to different customers (like a Ming vase or a painting by Claude Monet), increasing the number of bidders may be in the asset owners' interests. ${ }^{88}$

In the absence of agency costs, firms will balance the benefit of holding an auction for their shares (which comes in the form of a higher potential sales price) against the cost (which comes in the form of lower probability that an initial bid will be made due to the diminution in returns to bidders). But in the face of agency costs that pervade the large, publicly held corporation, the rule announced in Trans Union, which gives incumbent management broad discretion to reduce the probability that a hostile tender offer will ever be made, may dilute shareholders' prospects of increasing the odds of obtaining an outside bid for their shares.

Ultimately, we are left with competing costs and benefits. Our intuition is that Trans Union may be harmful to shareholders: the benefits of increasing the likelihood of auctions will tend to be outweighed by the costs in terms of beneficial takeover bids that are abandoned or never initiated, and increased investment banker and lawyer fees. Any adequate evaluation of the decision, however, must take into account the all-important implications of the fact that Trans Union is a takeover decision and not an ordinary business judgment case.

85. See Johnson, Auction Markets, Bid Preparation Costs and Entrance Fees, 55 LaND Econ. 313 (1979). Johnson suggests that the use of entry fees to restrict bidders will allow the seller to capture more of the gains from entry restrictions. Such entry fees may, however, be difficult to arrange in a tender offer context since potential bidders are not specified $e x$ ante.

86. See French \& McCormick, supra note 81, at 428-30. 
HeinOnline -- 98 Yale L. J. 144 1988-1989 